\title{
Interleukin-1 in the Response of Follicular Helper and Follicular Regulatory T Cells
}

\author{
Paul-Gydéon Ritvo ${ }^{1}$ and David Klatzmann ${ }^{1,2 *}$ \\ ${ }^{1}$ Sorbonne Université, INSERM, Immunology-Immunopathology-Immunotherapy (i3), Paris, France, ${ }^{2}$ AP-HP, Hôpital \\ Pitié-Salpêtrière, Biotherapy (CIC-BTi) and Inflammation-Immunopathology-Biotherapy Department (i2B), Paris, France
}

\section{OPEN ACCESS}

Edited by:

Maria Pia Cicalese, San Raffaele Scientific Institute

(IRCCS), Italy

Reviewed by:

Massimo Gadina,

National Institute of Arthritis and Musculoskeletal and Skin Diseases (NIAMS), United States

Michael Loran Dustin,

University of Oxford, United Kingdom

*Correspondence:

David Klatzmann

david.klatzmann@

sorbonne-universite.fr

Specialty section:

This article was submitted to

T Cell Biology,

a section of the journal

Frontiers in Immunology

Received: 27 July 2018

Accepted: 29 January 2019

Published: 27 February 2019

Citation:

Ritvo P-G and Klatzmann D (2019) Interleukin-1 in the Response of

Follicular Helper and Follicular

Regulatory T Cells.

Front. Immunol. 10:250.

doi: $10.3389 /$ fimmu.2019.00250
The role of interleukin-1 in the regulation of humoral responses is poorly documented, in contrast to its role in inflammation. Recent findings suggest there is an interleukin-1 axis in the follicular T cell control of B cell responses, involving interleukin-1 receptors (IL-1R1 and IL-1R2) and receptor antagonists (IL-1Ra). Here, we revisit the literature on this topic and conclude that targeting the interleukin-1 pathway should be a valuable therapeutic approach in many diseases involving excessive production of (auto)antibodies, such as autoimmune diseases or allergy.

Keywords: plasma cell, antibody production, immunoregulation, immunotherapy, germinal centers, Tfr cells, Tfh cells

\section{INTRODUCTION}

Interleukin-1 (IL-1) is known as the key cytokine of innate immune responses and has been described as the "quintessential inflammatory cytokine" (1). IL-1 is predominantly produced by monocytes and macrophages $(2,3)$ following an external stimulus such as through TollLike Receptor (TLR) activation. IL-1 pleiotropic functions have so far mainly been linked to inflammation, orchestrating a first line of defense against pathogens (4). IL-1 has systemic effects that trigger fever, cortisol production, and liver stimulation (with production of C-reactive and complement proteins) and local effects on innate and adaptive immune cell stimulation. The effects of IL-1 on innate immunity have been extensively studied and reviewed $(4,5)$. Those on adaptive immunity have been ascribed to a general amplification of T-cell responses (6) and to modulation of $\mathrm{T}$ cell plasticity toward Th17 cell differentiation $(7,8)$. Except for the known role of IL-1 in adjuvanticity (9), the involvement of IL-1 in the regulation of humoral response is poorly documented. Indeed, a thorough check of the literature, including multiple PubMed queries such as various combinations of "interleukin-1," "IL-1," "IL-1Ra," "IL-1R1," "IL-1R2," “Tfh," "Tfr" "follicular cells," "humoral immunity," "antibody production," "autoantibody production," and "germinal centers" did not identify relevant publications. We review here recent findings that highlight a key role of IL-1 in the regulation of follicular helper and follicular regulatory T cells, thereby controlling B cell responses.

\section{THE IL-1 ACTIVATION PATHWAY}

IL- $1 \beta$ is part of a wide family of cytokines (IL- $1 \alpha$, IL-1ß, IL-18, IL-33, IL-36), receptor antagonists (IL-1Ra, IL-36Ra, IL-38) and the anti-inflammatory IL-37. The IL-1 activation pathway has been reviewed elsewhere (10). Briefly, IL-1 is produced as an inactive precursor, pro-IL-1ß, in response to pathogen-specific signals. This stimulation of innate immune cells induces the formation of the 
inflammasome, a molecular scaffold composed of many molecules such as NLRP3 (11). This key system activates caspase 1 (also called ICE for Interleukin-1 Converting Enzyme), an enzyme able to cleave pro-IL-1ß (12). It is worthy of note that the mechanism of IL- $1 ß$ secretion is not the conventional endoplasmic reticulum and Golgi route (13), but is not well understood yet and may depend on many parameters, such as stimulus strength and IL-1 requirement (14).

The signaling pathway following the interaction of IL-1 with its agonist receptor IL-1R1 has been described to be the same as many other signaling pathways, such as those triggered by the interaction of pathogenic components with TLR or of IL33 with its receptor $(10,15)$. The first step consists of the recruitment of MyD88 to the receptors (16), and the cascade that follows-called the "canonical pathway" - which leads to the final activation of NF-kB. This ultimately activates the expression of pro-inflammatory genes such as cytokines, chemokines and adhesion molecules (17).

IL-1R2 and IL-1Ra regulate the IL-1ß / IL-1R1 interaction. IL-1R2 has an extracellular domain structurally similar to that of IL-1R1 but which lacks the intracellular domains allowing signaling. It thus acts as a decoy receptor, capturing the IL- $1 ß$ and thereby preventing IL-1R1 stimulation (18). IL-1R2 is expressed at high levels by macrophages, neutrophils and B-cells (19). IL$1 \mathrm{Ra}$ is a cytokine that inhibits IL-1 function by binding to IL-1R1 without producing any agonist effects, thereby preventing IL-1 binding $(20,21)$.

\section{IL-1 AND THE REGULATION OF TFH AND TFR CELLS}

Antibody production by plasma cells is tightly regulated by follicular helper T (Tfh) cells. Help by Tfh cells is essential for the differentiation of $\mathrm{B}$ cells into antibody-producing plasma cells $(22,23)$. In contrast, follicular regulatory $\mathrm{T}$ (Tfr) cells negatively control humoral immune responses $(24,25)$. These cells are thought to be derived from regulatory $\mathrm{T}$ (Treg) cells $(26,27)$. Their mechanisms of action are poorly known and they are thought to act by regulating the help provided by Tfh cells to B cells. However, recent findings have shown that few Tfr cells are located within the germinal centers (GCs) of LNs, where Tfh cells and plasma cells interact. Most Tfr cells are found surrounding the GCs and are likely not in contact with Tfh cells (28).

In contrast to Treg cells from which they are derived, we observed that Tfr cells do not respond to interleukin-2 (IL-2) (29). This led us to reexamine their phenotype thoroughly. In contrast to Treg cells and to previous description of the Tfrcell phenotype, we showed that Tfr cells do not express IL-2Ra (CD25), the essential component of the high-affinity IL-2R. This is important because most previous investigations of Tfr cell biology actually reported the biology of mixtures of Tfr and Treg cells. The stringent characterization of Tfr cells allowed us to reveal a striking distribution of IL-1 receptor expression on Tfh and Tfr cells. We observed that Th cells express the IL-1R1 agonist receptor while Tfr cells express both the IL-1R2 decoy receptor and the antagonist IL-1Ra. The lack of CD25 expression by Tfr cells and this distribution of IL-1 receptors have also been observed by others $(30,31)$.

This striking distribution of the agonist receptor on Th cells and of the antagonist receptors/inhibitors on Tfr cells led us to hypothesize and explore a possible IL-1 axis in the regulation of humoral responses. We observed that, in vitro, IL- $1 ß$ activated the production of IL- 4 and IL- 21 by Tfh cells. These cytokines have been shown to be crucial for the T-cell help to B cells (32). This cytokine production was suppressed by Tfr cells to the same extent as by recombinant IL-1Ra (Anakinra), indicating that the suppressive effect was likely dependent on the blocking of IL-1 by IL-1R2 on the surface of Tfr cells, or on IL-1Ra produced by Tfr cells. Eventually, we showed that, in vivo, IL-1ß induced proliferation of Tfh cells while Anakinra significantly reduced the proportion of Tfh cells.

Altogether, we revealed an IL-1 axis regulating the germinal center responses (29) and suggested the existence of a dual regulation of $\mathrm{T}$ cells in secondary lymphoid organs, one between Treg and effector T cells regulated by IL-2 outside GCs and the other between Tfh and Tfr cells regulated by IL-1 inside GCs.

\section{IL-1 AND REGULATION OF THE HUMORAL RESPONSE (FIGURE 1)}

There are no or few experiments that have investigated a direct link between IL-1 and antibody production. However, revisiting the literature, there are actually many observations indirectly supporting the involvement of an IL-1 axis in the control of humoral immunity (summarized in Table 1). First, IL-1 administration during an immunization enhanced humoral responses and led to greater antibody production $(9,38,39)$, a phenomenon referred to as the "adjuvanticity of IL-1," which was mostly thought to act by stimulation of innate immune cells that in turn would stimulate helper $\mathrm{T}$ cells to help $\mathrm{B}$ cells better. Interestingly, this observation is itself indirectly supported by the fact that many adjuvants used for immunization, such as the widely used alum, trigger enhanced IL-1 production (34). Similarly, stimulation by pathogens, which ultimately triggers antibody production, is also a strong IL-1 enhancer (35). Altogether, it appears that there is some positive correlation between production of IL-1 during immunization and the efficacy of the resulting B cell response.

Experiments using genetically modified mice not expressing the IL-1 gene or its receptors further support the importance of an IL-1 axis in the control of humoral responses. Following appropriate stimulation, IL-1-deficient mice produced significantly reduced amounts of antibodies compared to wild-type mice $(36,37)$. Conversely, mice deficient in the expression of IL-1Ra, an antagonist of the IL-1R1 receptor, showed increased antibody production in the same conditions $(36,37)$. In these studies, the effect of IL-1 on humoral immunity enhancement was shown to act through induction of costimulatory molecules on T cells, such as CD40L and OX40 (37), which were later found to be highly expressed on the surface of Tfh cells (40) (Table 1). 


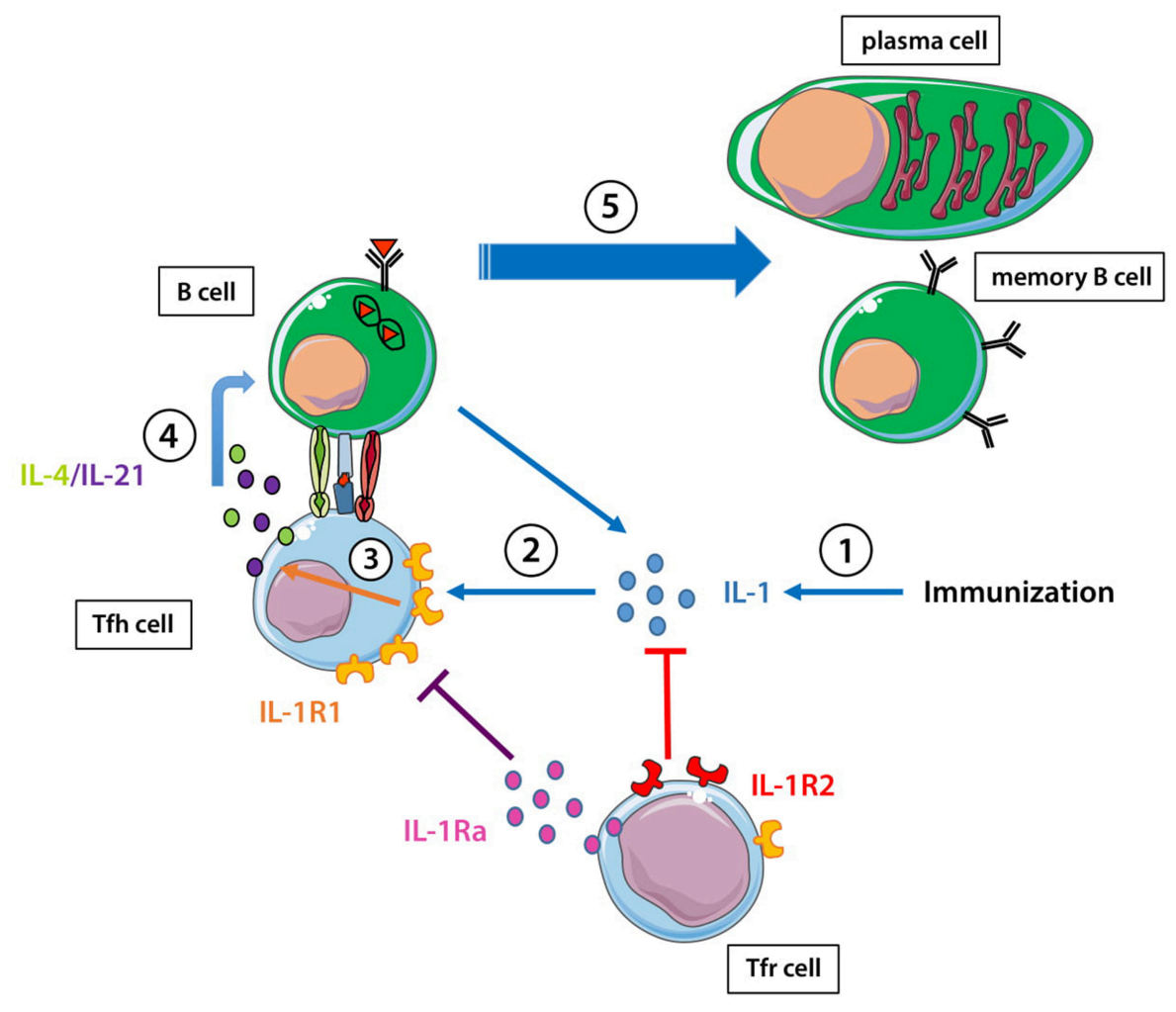

FIGURE 1 | IL-1 and the regulation of the humoral response. (1) Immunization enhances IL-1 production. (2) IL-1 stimulates tfh cells through the IL-1R1, can be captured by IL-1R2 on Tfr cells, and IL-1Ra produced by Tfr cells can block the action of IL-1 on IL-1R1. (3) IL-1 stimulates IL-4/IL-21 production by Tfh cells through its binding to IL-1R1. $(4,5)$ IL-4/IL-21 helps B cells to become either memory B cells or antibody-producing plasma cells.

\section{IL-1 AND THE PATHOPHYSIOLOGY OF HUMORAL RESPONSES}

Some evidence for the involvement of IL-1 in the humoral response can also be found by looking at diseases associated with excessive levels of antibodies and/or pathogenic antibodies.

\section{Autoimmune Diseases}

Autoantibody production is common in autoimmune diseases and frequently contributes to their pathophysiology. Much evidence of the involvement of IL-1 in the control of autoantibody production can be found in the recent literature.

One of the interesting models for the study of this role is Myasthenia Gravis (MG), a disease caused by a pathogenic anti-acetylcholine receptor (AChR) IgG1 (41). (i) IL-1ß gene polymorphisms have been found in association with MG, suggesting a possible pathogenic role of this cytokine in the disease (42); (ii) Anakinra reduced the clinical symptoms of mice with experimental autoimmune MG (EAMG) and suppressed the pathogenic anti-AChR IgG1 (41); (iii) inhibition of proteins involved in the production of IL-1ß, such as caspase-1, can regulate the humoral response in EAMG (43). In the classification by McGonagle and McDermott (44), MG is more an autoimmune than an auto-inflammatory disease. This suggests that the consequences of blocking IL-1 in this disease should mostly be due not to the blocking of IL-1 inflammatory effects, but to the contribution of IL-1 to the regulation of antibody production.

Thyroid gland autoimmune disorders also appear informative. (i) A recent large-scale study found an association with the IL-1 RN (gene encoding the IL-1Ra) receptor antagonist variable number of tandem repeats (VNTR) polymorphism in Hashimoto Thyroiditis (HT) patients (45); (ii) increased percentages of circulating Tfh cells have been found in patients with autoimmune thyroid disorders, with a positive correlation between the percentages of circulating Tfh cells and the serum concentrations of anti-TSH receptor- $\mathrm{Ab} /$ thyroperoxidase$\mathrm{Ab} /$ thyroglobulin- $\mathrm{Ab}$ (46); (iii) a study suggested that both promoter and exon polymorphisms of IL- $1 \beta$ gene have a significant role in the risk of developing Graves' disease (GD) (47); (iv) although no significant differences in IL-1 $\beta$ levels were found between serum from patients with HT or GD and normal controls. IL-1 $\beta$ mRNA and protein levels in peripheral blood mononuclear cells of HT patients were found to be significantly higher than those of patients with GD, which were in turn higher than the level in normal controls; (v) IL-1 $\beta$ mRNA was also increased in thyroid gland tissue from patients with HT compared to those with GD, and this was accompanied by increased local infiltration of monocytes into thyroid tissues; correlation analysis validated the association of 
TABLE 1 | Experiments supporting a correlation between IL-1 production during immunization and resulting antibody production.

\begin{tabular}{|c|c|c|c|}
\hline Experiment & Effect & Comment & References \\
\hline IL-1 as an adjuvant & Enhanced antibody response & $\begin{array}{l}\text { Dose- and time-dependent adjuvanticity of interleukin } 1 \text { in vivo. } \\
\text { IL-1 given } 2 \mathrm{~h} \text { after the priming dose of antigen enhanced antibody } \\
\text { response }\end{array}$ & (9) \\
\hline IL-1 as an adjuvant & Enhanced antibody response & $\begin{array}{l}\text { IL-1 is an effective mucosal vaccine adjuvant when } \\
\text { coadministered with protein immunogens, and is as effective as } \\
\text { cholera toxin in inducing Ag-specific serum IgG }\end{array}$ & (33) \\
\hline Cholera toxin induces release of IL-1 & Enhanced antibody response & $\begin{array}{l}\text { Cholera toxin }(C T) \text { is a strong systemic and mucosal adjuvant that } \\
\text { greatly enhances IgG and IgA immune responses. It stimulates } \\
\text { IL-1 production }\end{array}$ & (35) \\
\hline IL-1 $\alpha / \beta$-deficient mice & Reduced antibody production & $\begin{array}{l}\text { Primary and secondary antibody production against T-dependent } \\
\text { antigen was significantly reduced in IL-1 } 1 \alpha / \beta^{-/-} \text {mice after } \\
\text { immunization }\end{array}$ & $(36,37)$ \\
\hline IL-1 effects on CD40L & Increased CD4OL expression & $\begin{array}{l}\mathrm{CD} 40 \mathrm{~L} \text { expression on T cells was affected in } \mathrm{IL}-1^{-/-} \text {mice, and } \\
\text { the reduced } \mathrm{Ag} \text {-specific } \mathrm{B} \text { cell response in } \mathrm{IL}-1^{-/-} \text {mice was } \\
\text { recovered by treatment with agonistic anti-CD } 40 \text { mAb both in vitro } \\
\text { and in vivo. IL-1 enhances T cell-dependent } \mathrm{Ab} \text { production by } \\
\text { augmenting CD } 40 \mathrm{~L}\end{array}$ & (37) \\
\hline
\end{tabular}

high IL-1 $\beta$ levels with the pathogenesis of HT and led to the suggestion that IL-1 $\beta$ may be an active etiologic factor in the pathogenesis of HT and thus represent a new target for novel diagnostics and treatment (48).

Rheumatoid or systemic diseases could also be studied from this point of view. For instance, in rheumatoid arthritis, antiCCP antibodies were more frequently found in the rheumatoid arthritis subgroup with high levels of cytokines, including IL1 (49). In systemic lupus erythematosus (SLE) models, mice deficient in the IL-1ß gene were found to be resistant to induction of experimental SLE and developed lower levels of anti-dsDNA antibodies, as compared to control mice (50). Bay11-7082a broad-spectrum inhibitor with anti-inflammatory activity against multiple targets (51)_reduced autoantibody production and renal immune complex deposition in MRL/lpr mice via inhibiting NLRP3 inflammasome and NF- $\mathrm{BB}$ activation (52). Compared to wild-type mice, caspase $-1^{-/-}$mice had significant reductions in both anti-dsDNA and anti-RNP autoantibody titers, abrogation of a type I IFN signature and were protected from both renal immune complex deposition and kidney inflammation (53). A few studies reported efficacy of IL-1 blockers in SLE patients (54-56), with documented decrease in anti-dsDNA antibody levels $(54,55)$.

In multiple sclerosis (MS), some antibodies may be involved in the pathophysiology of some form of the disease via demyelination (57). Among these antibodies, autoantibodies directed against lipids present in myelin (58), myelin oligodendrocyte glycoprotein (MOG) (59) or myelin basic protein (60) could be pathogenic, possibly through antibody deposition and complement activation, which are frequently found in chronic active lesions (61). Supporting this, new brain lesions were reduced in MS patients receiving rituximab, an anti-CD20 drug that depletes B cells (62). Therapeutic plasma exchange has also been used to treat the disease, with success in the MS pattern involving prominent immunoglobulin and complement (63). On the other hand, IL-1ß expression in the central nervous system and in blood has been shown to be associated with disease activity, though direct mechanisms have not been established (64). IL-1R1-deficient mice were resistant to experimental autoimmune encephalomyelitis (EAE) (65), the mouse model of MS. Furthermore, treatment with IL-1Ra has some protective effect on rat EAE as it reduces the duration and severity of the disease (66). Altogether, this could be suggestive of an effect of the IL-1 axis on the disease through limitation of pathogenic antibody production in MS.

In celiac disease, individuals develop an immune reaction to gluten, mainly composed of IgA antibodies. Polymorphism of IL-1 has been associated with susceptibility to celiac disease (67) and IL- $1 ß$ is associated with the disease, though its mechanism of action is unknown (68). Finally, we recently showed that the TCR repertoires of Tfh and Tfr cells from spleens of immunised mice were surprisingly diverse and mostly composed of mildly expanded clonotypes suggesting a major bystander activation during the immune response in the GCs (69). It remains to investigate the contribution of IL-1 to this bystander activation and its possible relation to autoantibody formation.

\section{Hypersensitivity and Allergy}

Allergy also appears of interest in supporting the involvement of IL-1 in antibody production. In 2012, preliminary results suggested that IL-1ß was involved in the development of antigenspecific Tfh cells in the airways (70). Since these results, it 
has been shown that exposure to IL-1ß in conjunction with ovalbumin leads to significant increases in the levels of specific anti-OVA IgE and IgG $(71,72)$. Mice that are deficient in the IL$1 \mathrm{R} 1$ receptor and sensitized to peanut for 4 weeks showed a large decrease in serum levels of peanut-specific IgE antibodies, as well as anti-peanut IgG1 antibodies. Numbers of Tfh and GC B cells were also dramatically decreased in IL- $1 \mathrm{R} 1^{-/}$mice compared to wild-type mice (73). The role of IL-1 in the pathogenesis of allergies was also suggested by studies showing, for instance, that administration of IL-1Ra to pigs reduced IgE production. Finally, in humans, polymorphisms of IL-1-related genes have been associated with susceptibility to allergic rhinitis (74).

\section{LESSONS FROM THERAPEUTIC TRIALS}

Different molecules targeting IL-1 have been or are currently being developed. Among them are monoclonal antibodies directed against IL-1 (Canakinumab, Gevokizumab for instance), a human recombinant IL-1Ra (Anakinra) or a soluble decoy receptor (Rilonacept) (75). Despite widespread use of these IL1 inhibitors in patients with autoimmune disease, very little has been reported concerning a modification of the humoral response. The only possibly relevant findings are of an increased incidence of infection compared with placebo, but no data have been presented that could support a link with regulation of humoral responses (76).

\section{CONCLUSIONS-PERSPECTIVES}

The notion that an IL-1 axis might control humoral immune responses by Tfh and Tfr cells is just emerging. Although it was well known that IL-1 has an important role in immune responses that lead to antibody production, this role was mostly assigned to direct stimulation of an innate immune response, which in turn would control the T and B cell response independently of IL-1. The discovery of a peculiar distribution of IL-1 receptors and IL1 antagonists on Tfh and Tfr cells led us to revisit the role of IL-1 in the control of antibody production. It is now clear that most Tfh cells from the GCs express IL-1R1 and that in a pure in vitro system the addition of IL-1 directly stimulates Tfh to produce the two main B-cell activation cytokines. Furthermore, IL-1 alone

\section{REFERENCES}

1. Dinarello, CA. A clinical perspective of $\mathrm{IL}-1 \beta$ as the gatekeeper of inflammation. Eur J Immunol. (2011) 41:1203-17. doi: 10.1002/eji.201141550

2. Dinarello Charles A. Interleukin-1 $\beta$, interleukin-18, and the interleukin$1 \beta$ converting enzymea. Ann NY Acad Sci. (2006) 856:1-11. doi: 10.1111/j.1749-6632.1998.tb08307.x

3. Beuscher HU, Günther C, Röllinghoff M. IL-1 beta is secreted by activated murine macrophages as biologically inactive precursor. J Immunol. (1990) 144:2179-83.

4. The Interleukin-1 Family: Back to the Future-ScienceDirect. Available online at: https://www.sciencedirect.com/science/article/pii/S1074761313005153. (Accessed June 9, 2018)

5. Mantovani A, Cassatella MA, Costantini C, Jaillon S. Neutrophils in the activation and regulation of innate and adaptive immunity. Nat Rev Immunol. (2011) 11:519-31. doi: 10.1038/nri3024 expands Tfh in vivo. Thus, a direct role of IL-1 in the activation of Tfh cells appears important for antibody production.

The role of Tfr in controlling this regulation is less well documented. Tfr cells express IL-1R2 and IL-1Ra and are thus equipped to interfere with IL-1-mediated activation of Tfh cells. Recent work has localized most Tfr cells around and not inside GCs, which would be compatible with a role in capturing/neutralizing IL-1 before it can act on Tfh cells (27). Further studies, notably assessing mice knockout for the different receptors on specific cell populations should clarify the mechanistic aspects of the IL-1 axis in Tfr/Tfh cell control of antibody production.

Meanwhile, an existing and large body of evidence indicates that targeting the IL-1 pathway should be an important, although so far ignored, therapeutic approach to many autoimmune diseases. It could work not just by reducing inflammation, which can be fueled by the antibody response, but also by directly reducing this antibody response, thus playing both sides for greater efficacy. By reducing inflammation, it can also improve the efficacy of Tregs which suppressive ability is decreased in high inflammatory context (77-80). We believe that these results should stimulate the investigation of the regulation of IL-1 in many experimental models, from autoimmunity and inflammation to allergy. Furthermore, given the availability of many drugs targeting the IL-1 pathway, and acknowledging that our experimental models of diseases do not reflect human settings of diseases well, innovative clinical trials should play a role in further elucidation of the IL-1 pathway and its therapeutic potential.

\section{AUTHOR CONTRIBUTIONS}

All authors listed have made a substantial, direct and intellectual contribution to the work, and approved it for publication.

\section{FUNDING}

P-GR is an Ecole de l'Inserm Liliane Bettencourt doctoral fellow. This work has been supported the LabEx Transimmunom (ANR11-IDEX-0004-02), ERC-Advanced TRiPoD (322856) and RHU iMAP grants to DK.

6. Sims JE, Smith DE. The IL-1 family: regulators of immunity. Nat Rev Immunol. (2010) 10:89-102. doi: 10.1038/nri2691

7. Santarlasci V, Cosmi L, Maggi L, Liotta F, Annunziato F. IL-1 and $\mathrm{T}$ helper immune responses. Front Immunol. (2013) 4:182. doi: 10.3389/fimmu.2013.00182

8. Kryczek I, Wei S, Vatan L, Escara-Wilke J, Szeliga W, Keller ET, et al. Cutting edge: opposite effects of IL-1 and IL-2 on the regulation of IL-17+ T cell pool IL-1 subverts IL-2-mediated suppression. J Immunol. (2007) 179:1423-6. doi: 10.4049/jimmunol.179.3.1423

9. Staruch MJ, Wood DD. The adjuvanticity of interleukin 1 in vivo. J Immunol. (1983) 130:2191-4.

10. Weber A, Wasiliew P, Kracht M. Interleukin-1 (IL-1) pathway. Sci Signal. (2010) 3:cm1. doi: 10.1126/scisignal.3105 $\mathrm{cm} 1$

11. Latz E, Xiao TS, Stutz A. Activation and regulation of the inflammasomes. Nat Rev Immunol. (2013) 13:397-411. doi: 10.1038/nr i3452 
12. Thornberry NA, Bull HG, Calaycay JR, Chapman KT, Howard AD, Kostura MJ, et al. A novel heterodimeric cysteine protease is required for interleukin-1 beta processing in monocytes. Nature (1992) 356:768-74. doi: $10.1038 / 356768 \mathrm{a} 0$

13. Rubartelli A, Cozzolino F, Talio M, Sitia R. A novel secretory pathway for interleukin-1 beta, a protein lacking a signal sequence. EMBO J. (1990) 9:1503-10. doi: 10.1002/j.1460-2075.1990.tb08268.x

14. Lopez-Castejon G, Brough D. Understanding the mechanism of IL-1 secretion. Cytokine Growth Factor Rev. (2011) 22:189-95. doi: 10.1016/j.cytogfr.2011.10.001

15. Cohen P. The TLR and IL-1 signalling network at a glance. J Cell Sci. (2014) 127:2383-90. doi: 10.1242/jcs.149831

16. Kawai T, Akira S. The role of pattern-recognition receptors in innate immunity: update on Toll-like receptors. Nat Immunol. (2010) 11:373-84. doi: $10.1038 /$ ni.1863

17. Karin M, Ben-Neriah Y. Phosphorylation meets ubiquitination: the control of NF-[kappa]B activity. Annu Rev Immunol. (2000) 18:621-63. doi: 10.1146/annurev.immunol.18.1.621

18. Peters VA, Joesting JJ, Freund GG. IL-1 receptor 2 (IL-1R2) and its role in immune regulation. Brain Behav Immun. (2013) 32:1-8. doi: 10.1016/j.bbi.2012.11.006

19. Molgora M, Supino D, Mantovani A, Garlanda C. Tuning inflammation and immunity by the negative regulators IL-1R2 and IL-1R8. Immunol Rev. (2018) 281:233-47. doi: 10.1111/imr.12609

20. Seckinger P, Lowenthal JW, Williamson K, Dayer JM, MacDonald HR. A urine inhibitor of interleukin 1 activity that blocks ligand binding. J Immunol. (1987) 139:1546-9.

21. Volarevic V, Al-Qahtani A, Arsenijevic N, Pajovic S, Lukic ML. Interleukin1 receptor antagonist (IL-1Ra) and IL-1Ra producing mesenchymal stem cells as modulators of diabetogenesis. Autoimmunity (2010) 43:255-63. doi: 10.3109/08916930903305641

22. Crotty S. T follicular helper cell differentiation, function, and roles in disease. Immunity (2014) 41:529-42. doi: 10.1016/j.immuni.2014.10.004

23. Wing JB, Tekgüç M, Sakaguchi S. Control of germinal center responses by T-follicular regulatory cells. Front Immunol. (2018) 9:1910. doi: 10.3389/fimmu.2018.01910

24. Chung Y, Tanaka S, Chu F, Nurieva R, Martinez GJ, Rawal S, et al. Follicular regulatory $\mathrm{T}$ (Tfr) cells with dual Foxp3 and Bcl6 expression suppress germinal center reactions. Nat Med. (2011) 17:983-8. doi: 10.1038/nm.2426

25. Linterman MA, Pierson W, Lee SK, Kallies A, Kawamoto S, Rayner TF, et al. Foxp3+ follicular regulatory $\mathrm{T}$ cells control $\mathrm{T}$ follicular helper cells and the germinal center response. Nat Med. (2011) 17:975-82. doi: 10.1038/nm.2425

26. Wollenberg I, Agua-Doce A, Hernández A, Almeida C, Oliveira VG, Faro J, et al. Regulation of the germinal center reaction by Foxp3+ follicular regulatory $\mathrm{T}$ cells. J Immunol. (2011) 187:4553-60. doi: 10.4049/jimmunol.1101328

27. Aloulou M, Carr EJ, Gador M, Bignon A, Liblau RS, Fazilleau N, et al. Follicular regulatory $\mathrm{T}$ cells can be specific for the immunizing antigen and derive from naive T cells. Nat Commun. (2016) 7:10579. doi: 10.1038/ncomms10579

28. Sayin I, Radtke AJ, Vella LA, Jin W, Wherry EJ, Buggert M, et al. Spatial distribution and function of $\mathrm{T}$ follicular regulatory cells in human lymph nodes. J Exp Med. (2018) 215:1531-42. doi: 10.1084/jem.20171940

29. Ritvo PG, Churlaud G, Quiniou V, Florez L, Brimaud F, Fourcade G, et al. Tfr cells lack IL-2R $\alpha$ but express decoy IL-1R2 and IL-1Ra and suppress the IL-1-dependent activation of Tfh cells. Sci Immunol. (2017) 2:eaan0368. doi: 10.1126/sciimmunol.aan0368

30. Botta D, Fuller MJ, Marquez-Lago TT, Bachus H, Bradley JE, Weinmann $\mathrm{AS}$, et al. Dynamic regulation of $\mathrm{T}$ follicular regulatory cell responses by interleukin 2 during influenza infection. Nat Immunol. (2017) 18:1249-60. doi: $10.1038 /$ ni.3837

31. Wing JB, Kitagawa Y, Locci M, Hume H, Tay C, Morita $T$, et al. A distinct subpopulation of CD25- T-follicular regulatory cells localizes in the germinal centers. Proc Natl Acad Sci USA. (2017) 114:E6400-9. doi: 10.1073/pnas.1705551114

32. Avery DT, Bryant VL, Ma CS, de Waal Malefyt R, Tangye SG. IL21-induced isotype switching to $\operatorname{IgG}$ and $\operatorname{IgA}$ by human naive $\mathrm{B}$ cells is differentially regulated by IL-4. J Immunol. (2008) 181:1767-79. doi: 10.4049/jimmunol.181.3.1767

33. Staats HF, Ennis FA. IL-1 is an effective adjuvant for mucosal and systemic immune responses when coadministered with protein immunogens. J Immunol. (1999) 162:6141-7.

34. Li H, Nookala S, Re F. Aluminum hydroxide adjuvants activate caspase1 and induce IL-1beta and IL-18 release. J Immunol. (2007) 178:5271-6. doi: 10.4049/jimmunol.178.8.5271

35. Bromander A, Holmgren J, Lycke N. Cholera toxin stimulates IL-1 production and enhances antigen presentation by macrophages in vitro. J Immunol. (1991) 146:2908-14.

36. Nakae S, Asano M, Horai R, Iwakura Y. Interleukin-1 beta, but not interleukin-1 alpha, is required for T-cell-dependent antibody production. Immunology (2001) 104:402-9. doi: 10.1046/j.1365-2567.2001.01337.x

37. Nakae S, Asano M, Horai R, Sakaguchi N, Iwakura Y. IL-1 enhances T celldependent antibody production through induction of CD40 ligand and OX40 on T cells. J Immunol. (2001) 167:90-7. doi: 10.4049/jimmunol.167.1.90

38. Nencioni L, Villa L, Tagliabue A, Antoni G, Presentini R, Perin F, et al. In vivo immunostimulating activity of the 163-171 peptide of human IL-1 beta. J Immunol. (1987) 139:800-4.

39. Reed SG, Pihl DL, Conlon PJ, Grabstein KH. IL-1 as adjuvant. Role of T cells in the augmentation of specific antibody production by recombinant human IL-1 alpha. J Immunol. (1989) 142:3129-33.

40. Li H, Pauza CD. CD25+Bcl6low T follicular helper cells provide help to maturing B cells in germinal centers of human tonsil. Eur J Immunol. (2015) 45:298-308. doi: 10.1002/eji.201444911

41. Yang H, Tüzün E, Alagappan D, Yu X, Scott BG, Ischenko A, et al. IL1 receptor antagonist-mediated therapeutic effect in murine myasthenia gravis is associated with suppressed serum proinflammatory cytokines, C3, and anti-acetylcholine receptor IgG1. J Immunol. (2005) 175:2018-25. doi: 10.4049/jimmunol.175.3.2018

42. Huang D, Pirskanen R, Hjelmström P, Lefvert AK. Polymorphisms in IL-1beta and IL-1 receptor antagonist genes are associated with myasthenia gravis. J Neuroimmunol. (1998) 81:76-81. doi: 10.1016/S0165-5728(97)00161-6

43. Wang CC, Zhang M, Li H, Li XL, Yue LT, Zhang P, et al. Caspase-1 inhibitor regulates humoral responses in experimental autoimmune myasthenia gravis via IL-6- dependent inhibiton of STAT3. Neurosci Lett. (2017) 656:169-76. doi: 10.1016/j.neulet.2017.05.040

44. McGonagle D, McDermott MF. A proposed classification of the immunological diseases. PLoS Med. (2006) 3:e297. doi: 10.1371/journal.pmed.0030297

45. Yoo WS, Chung HK. Recent advances in autoimmune thyroid diseases. Endocrinol Metab. (2016) 31:379-85. doi: 10.3803/EnM.2016.31.3.379

46. Zhu C, Ma J, Liu Y, Tong J, Tian J, Chen J, et al. Increased frequency of follicular helper T cells in patients with autoimmune thyroid disease. J Clin Endocrinol Metab. (2012) 97:943-50. doi: 10.1210/jc.2011-2003

47. Shehjar F, Afroze D, Misgar RA, Malik SA, Laway BA. Association of polymorphic variants of IL-1 $\beta$ and IL-1RN genes in the development of Graves' disease in Kashmiri population (North India). Hum Immunol. (2018) 79:228-32. doi: 10.1016/j.humimm.2018.02.006

48. Sun L, Zhang X, Dai F, Shen J, Ren C, Zuo C, et al. Elevated interleukin$1 \beta$ in peripheral blood mononuclear cells contributes to the pathogenesis of autoimmune thyroid diseases, especially of Hashimoto thyroiditis. Endocr Res. (2016) 41:185-92. doi: 10.3109/07435800.2015.1124439

49. Johnsen AK, Plenge RM, Butty V, Campbell C, Dieguez-Gonzalez R, GomezReino JJ, et al. A broad analysis of IL1 polymorphism and rheumatoid arthritis. Arthritis Rheum. (2008) 58:1947-57. doi: 10.1002/art.23592

50. Voronov E, Dayan M, Zinger H, Gayvoronsky L, Lin JP, Iwakura Y, et al. IL-1 beta-deficient mice are resistant to induction of experimental SLE. Eur Cytokine Netw. (2006) 17:109-16

51. Lee J, Rhee MH, Kim E, Cho JY. BAY 11-7082 is a broad-spectrum inhibitor with anti-inflammatory activity against multiple targets. Mediators Inflamm. (2012) 2012:416036. doi: 10.1155/2012/416036

52. Zhao J, Zhang $\mathrm{H}$, Huang $\mathrm{Y}$, Wang $\mathrm{H}$, Wang $\mathrm{S}$, Zhao $\mathrm{C}$, et al. Bay11-7082 attenuates murine lupus nephritis via inhibiting NLRP3 inflammasome and NF- $\kappa$ B activation. Int Immunopharmacol. (2013) 17:11622. doi: 10.1016/j.intimp.2013.05.027 
53. Kahlenberg JM, Yalavarthi S, Zhao W, Hodgin JB, Reed TJ, Tsuji NM, et al. An essential role of caspase 1 in the induction of murine lupus and its associated vascular damage. Arthritis Rheumatol. (2014) 66:152-62. doi: 10.1002/art.38225

54. Moosig F, Zeuner R, Renk C, Schröder JO. IL-1RA in refractory systemic lupus erythematosus. Lupus (2004) 13:605-6. doi: 10.1191/0961203304lu1047cr

55. Ostendorf B, Iking-Konert C, Kurz K, Jung G, Sander O, Schneider M. Preliminary results of safety and efficacy of the interleukin 1 receptor antagonist anakinra in patients with severe lupus arthritis. Ann Rheum Dis. (2005) 64:630-3. doi: 10.1136/ard.2004.025858

56. Tayer-Shifman OE, Ben-Chetrit E. Refractory macrophage activation syndrome in a patient with SLE and APLA syndrome-successful use of PETCT and Anakinra in its diagnosis and treatment. Mod Rheumatol. (2015) 25:954-7. doi: 10.3109/14397595.2013.844403

57. Elliott C, Lindner M, Arthur A, Brennan K, Jarius S, Hussey J, et al. Functional identification of pathogenic autoantibody responses in patients with multiple sclerosis. Brain J Neurol. (2012) 135:1819-33. doi: 10.1093/brain/ aws 105

58. Kanter JL, Narayana S, Ho PP, Catz I, Warren KG, Sobel RA, et al. Lipid microarrays identify key mediators of autoimmune brain inflammation. Nat Med. (2006) 12:138-43. doi: 10.1038/nm1344

59. O'Connor KC, Appel H, Bregoli L, Call ME, Catz I, Chan JA, et al. Antibodies from inflamed central nervous system tissue recognize myelin oligodendrocyte glycoprotein. J Immunol. (2005) 175:1974-82. doi: 10.4049/jimmunol.175.3.1974

60. O'Connor KC, Chitnis T, Griffin DE, Piyasirisilp S, Bar-Or A, Khoury $\mathrm{S}$, et al. Myelin basic protein-reactive autoantibodies in the serum and cerebrospinal fluid of multiple sclerosis patients are characterized by low-affinity interactions. J Neuroimmunol. (2003) 136:140-8. doi: 10.1016/S0165-5728(03)00002-X

61. Wu GF, Alvarez E. The immuno-pathophysiology of multiple sclerosis. Neurol Clin. (2011) 29:257-78. doi: 10.1016/j.ncl.2010.12.009

62. Hauser SL, Waubant E, Arnold DL, Vollmer T, Antel J, Fox RJ, et al. B-cell depletion with rituximab in relapsing-remitting multiple sclerosis. N Engl J Med. (2008) 358:676-88. doi: 10.1056/NEJMoa 0706383

63. Keegan M, König F, McClelland R, Brück W, Morales Y, Bitsch A, et al. Relation between humoral pathological changes in multiple sclerosis and response to therapeutic plasma exchange. Lancet (2005) 366:579-82. doi: 10.1016/S0140-6736(05)67102-4

64. Lin C-C, Edelson BT. New insights into the role of IL-1 $\beta$ in experimental autoimmune encephalomyelitis and multiple sclerosis. J Immunol. (2017) 198:4553-60. doi: 10.4049/jimmunol.1700263

65. Schiffenbauer J, Streit WJ, Butfiloski E, LaBow M, Edwards C, Moldawer LL. The induction of EAE is only partially dependent on TNF receptor signaling but requires the IL-1 type I receptor. Clin Immunol. (2000) 95:117-23. doi: 10.1006/clim.2000.4851

66. Martin D, Near SL. Protective effect of the interleukin-1 receptor antagonist (IL-1ra) on experimental allergic encephalomyelitis in rats. J Neuroimmunol. (1995) 61:241-5. doi: 10.1016/0165-5728(95)00108-E

67. Cherñavsky AC, Páez MC, Periolo N, Correa P, Guillén L, Niveloni SI, et al. The simultaneous presence of IL-1B and TNFA two-positions risk haplotypes enhances the susceptibility for celiac disease. Cytokine (2008) 42:48-54. doi: 10.1016/j.cyto.2008.01.015

68. Palová-Jelínková L, Dánová $\mathrm{K}$, Drašarová $\mathrm{H}$, Dvorák M, Funda DP, Fundová $\mathrm{P}$, et al. Pepsin digest of wheat gliadin fraction increases production of IL-1 $\beta$ via TLR4/MyD88/TRIF/MAPK/NF-kB signaling pathway and an NLRP3 inflammasome activation. PLoS ONE (2013) 8:e62426. doi: 10.1371/journal.pone.0062426

69. Ritvo PG, Saadawi A, Barennes P, Quiniou V, Chaara W, El Soufi $\mathrm{K}$, et al. High-resolution repertoire analysis reveals a major bystander activation of Tfh and Tfr cells. Proc Natl Acad Sci USA (2018) 115:9604-9. doi: 10.1073/pnas.1808594115

70. Kobayashi T, Iijima, K, Kita, H. Exposure to IL-1-family cytokines regulates differential development of antigen-specific Th2 cells and $\mathrm{T}$ follicular helper (Tfh) cells in the airway. J Allergy Clin Immunol. (2012) 129:AB145. doi: $10.1016 /$ j.jaci.2011.12.487

71. Kobayashi T, Iijima K, Dent AL, Kita H. Follicular helper T (Tfh) cells mediate IgE antibody response to airborne allergens. J Allergy Clin Immunol. (2017) 139:300-313.e7. doi: 10.1016/j.jaci.2016.04.021

72. Kobayashi T, Iijima K, Checkel JL, Kita H. IL-1 family cytokines drive Th2 and Th17 cells to innocuous airborne antigens. Am J Respir Cell Mol Biol. (2013) 49:989-98. doi: 10.1165/rcmb.2012-0444OC

73. Dolence JJ, Kobayashi T, Iijima K, Krempski J, Drake LY, Dent AL, et al. Airway exposure initiates peanut allergy by involving the IL-1 pathway and T follicular helper cells in mice. J Allergy Clin Immunol. (2018) 142:1145-58. doi: 10.1016/j.jaci.2017.11.020

74. Nambu A, Nakae, S. IL-1 and allergy. Allergol Int. 59:125-35 (2010). doi: 10.2332/allergolint.10-RAI-0190

75. Dinarello CA, Simon A, van der Meer JWM. Treating inflammation by blocking interleukin-1 in a broad spectrum of diseases. Nat Rev Drug Discov. (2012) 11:633-52. doi: 10.1038/nrd3800

76. Winthrop KL, Mariette X, Silva JT, Benamu E, Calabrese LH, Dumusc A, et al. ESCMID Study Group for Infections in Compromised Hosts (ESGICH) consensus document on the safety of targeted and biological therapies: an infectious diseases perspective (Soluble immune effector molecules [II]: agents targeting interleukins, immunoglobulins and complement factors). Clin Microbiol Infect. (2018) 24(Suppl. 2):S21-40. doi: 10.1016/j.cmi.2018.02.002

77. Billiard F, Litvinova E, Saadoun D, Djelti F, Klatzmann D, Cohen $\mathrm{JL}$, et al. Regulatory and effector $\mathrm{T}$ cell activation levels are prime determinants of in vivo immune regulation. J Immunol. (2006) 177:2167-74. doi: 10.4049/jimmunol.177.4.2167

78. Klatzmann D, Abbas AK. The promise of low-dose interleukin-2 therapy for autoimmune and inflammatory diseases. Nat Rev Immunol. (2015) 15:283-94. doi: $10.1038 /$ nri3823

79. Li Z, Lin F, Zhuo C, Deng G, Chen Z, Yin S, et al. PIM1 kinase phosphorylates the human transcription factor FOXP3 at serine 422 to negatively regulate its activity under inflammation. J Biol Chem. (2014) 289:26872-81. doi: 10.1074/jbc.M114.586651

80. Yamaguchi T, Wing JB, Sakaguchi S. Two modes of immune suppression by Foxp3(+) regulatory $\mathrm{T}$ cells under inflammatory or non-inflammatory conditions. Semin Immunol. (2011) 23:424-30. doi: 10.1016/j.smim.2011.10.002

Conflict of Interest Statement: The authors declare that the research was conducted in the absence of any commercial or financial relationships that could be construed as a potential conflict of interest.

Copyright (c) 2019 Ritvo and Klatzmann. This is an open-access article distributed under the terms of the Creative Commons Attribution License (CC BY). The use, distribution or reproduction in other forums is permitted, provided the original author(s) and the copyright owner(s) are credited and that the original publication in this journal is cited, in accordance with accepted academic practice. No use, distribution or reproduction is permitted which does not comply with these terms. 